\title{
ANALISIS CASH WAQF LINKED SUKUK (CWLS) DALAM PERSPEKTIF MAQÂSHID ASY-SYARI''AH
}

\author{
Rahmatul Fadhil ${ }^{1} \&$ Nurbalqis ${ }^{2}$
}

\begin{abstract}
Abstrak
Cash Waqf Linked Sukuk (CWLS) termasuk produk creative financing baru dari Indonesia dan pertama di dunia, yang menghasilkan dampak keberkahan sepanjang masa. Di Indonesia pemanfaatan wakaf produktif menjadi indikator peningkatan perwakafan yang progresif, karena apabila asetnya dikelola dapat menghasilkan keuntungan secara ekonomis. Disisi lain, melihat begitu signifikan dan kontribusi Cash Waqf Linked Sukuk (CWLS) ini dalam mengembangkan ekonomi umat, serta ditopang oleh sifat inovasi sebagai karakter utama, maka perlu di analisis kesesuaian akad yang digunakan dan mekanismenya dengan berpijak pada prinsip Maqâshid asy-Syarî'ah. Penelitian ini menggunakan metode penelitian kepustakaan (library research). Adapun sumber data yang digunakan adalah data-data primer dan sekunder. Data di analisis dengan menggunakan metode deskriptif analisis. Hasil penelitian ini menunjukkan bahwa: berdasarkan tinjauan dari perspektif Maqâshid asy-Syarî'ah transaksi Cash Waqf Linked Sukuk (CWLS) termasuk kategori hifdz al-mâl tingkat al-hâjiyyât dan hifdz ad-dîn tingkat al-hâjiyyât.
\end{abstract}

Kata Kunci: Cash Waqf Linked Sukuk, Maqâshid Asy-Syarî’ah

\section{Abstract}

Cash Waqf Linked Sukuk (CWLS) is a new creative financing product from Indonesia and the first in the world, which has a lasting impact. In Indonesia, the use of productive waqf is an indicator of a progressive increase in waqf, because if the assets are managed, they can generate economic benefits. On the other hand, seeing the significant and significant contribution of Cash Waqf Linked Sukuk (CWLS) in developing the people's economy, and supported by the nature of innovation as the main character, it is necessary to analyze the suitability of the contract used and its mechanism based on the Maqâshid ash-Syarî'ah principle. . This study uses library research methods (library research). The data sources used are primary and secondary data. The data were analyzed using descriptive analysis method. The results of this study indicate that: based on a review from the perspective of Maqâshid ash-Syarî'ah Cash Waqf Linked Sukuk (CWLS) transactions are included in the category of ifdz al-mâl at the level of al-hâjiyyât and ifdz ad-dîn at the level of al-hâjiyyât.

Keywords: Cash Waqf Linked Sukuk, Maqâshid Asy-Syarî'ah

\footnotetext{
${ }^{1}$ Institut Ilmu Al-Qur'an (IIQ) Jakarta,

Email: Rahmatul.fadhil@iiq.ac.id

${ }^{2}$ Institut Ilmu Al-Qur'an (IIQ) Jakarta,
} 


\section{A. PENDAHULUAN}

Berlakunya Undang-Undang No. 41 Tahun 2004 tentang wakaf, mengubah paradigma masyarakat tentang wakaf. Wakaf tidak lagi dinilai sebagai sarana untuk mendermakan harta yang dialokasikan untuk tempat dan sarana ibadah saja. Akan tetapi, peruntukan dan pemanfaatan harta wakaf telah mengalami perkembangan yang sangat pesat di Indonesia. Ada istilah wakaf produktif yang terbagi menjadi wakaf tunai, wakaf aset manfaat, wakaf pengalihan hak, wakaf surat berharga, wakaf profesi hingga wakaf kolektif.

Wakaf Uang (Cash Waqf) adalah perbuatan hukum Wakif untuk memisahkan dan/atau menyerahkan sebagian uang miliknya untuk dimanfaatkan selamanya atau untuk jangka waktu tertentu sesuai dengan kepentingannya guna keperluan ibadah dan/atau kesejahteraan umum menurut syariah.

Di Indonesia, sebelum lahir UU No. 4 tahun 2004, Majelis Ulama Indonesia (MUI) telah mengeluarkan Fatwa tentang Wakaf Uang, (11/5/2002):

1. Wakaf Uang (Cash Waqf/ Waqf al-Nuqud) adalah wakaf yang dilakukan seseorang, kelompok orang, lembaga, atau badan hukum dalam bentuk uang tunai.

2. Termasuk ke dalam pengertian uang adalah surat-surat berharga.

3. Wakaf Uang hukumnya jawaz (boleh)

4. Wakaf Uang hanya boleh disalurkan dan digunakan untuk halhal yang dibolehkan secara syar'i.

5. Nilai pokok wakaf uang harus dijamin kelestariannya, tidak boleh dijual, dihibahkan, dan/atau diwariskan.

Wakaf Uang ternyata telah dipraktikkan sejak awal abad kedua hijriyah, diriwayatkan oleh Imam Bukhari bahwa Imam al-Zuhri (wafat $124 \mathrm{H}$ ) salah seorang ulama dan peletak dasar kodifikasi Hadis (tadwin al-Hadis) menfatwakan, dianjurkan wakaf uang Dinar dan Dirham untuk pembangunan sarana dakwah, sosial dan pendidikan Umat Islam. Adapun caranya adalah dengan menjadikan uang tersebut sebagai modal usaha kemudian menyalurkan keuntungannya sebagai wakaf.

Wakaf Uang sudah diketahui pada periode Usmaniyah dan juga Mesir Walaupun demikian, pemanfaatan wakaf uang sebagai instrumen keuangan benar-benar merupakan inovasi dalam keuangan 
publik Islam. Praktik wakaf uang ini dipelopori oleh M. A. Mannan dan pertama kali dilangsungkan di Social Investment Bank Ltd. (SIBL) DhakaBangladesh yang telah berdiri sejak 22 November 1995 dan telah mempromosikan sertifikat wakaf uang pada Desember 1997, kemudian menerbitkan secara formal pada 12 Januari 1998 dengan pola menjamin keutuhan modal (mauquf) dan hasilnya digunakan untuk kesejahteraan sosial (mauquf 'alaih). Sehingga dapat dikatakan bahwa operasional wakaf uang yang dilakukan SIBL mampu memberi pengalaman dan contoh nyata proses pemanfaatan sertifikat wakaf uang sebagai instrumen keuangan pada perbankan.

Wakaf uang memang nyata seperti instrumen keuangan Islam lainnya yaitu Zakat, Infak, Sedekah (ZIS). Akan tetapi, yang membedakan adalah ZIS bisa dibagi-bagikan langsung dana pokoknya kepada pihak yang berhak. Sementara pada wakaf uang, uang pokoknya akan di investasikan dan keuntungan investasi dari pokok itulah yang akan mendanai kebutuhan rakyat miskin. Wakaf uang diinvestasikan dalam wujud saham atau deposito, atau lebih akuratnya nilai uang tetap terjaga dan menghasilkan keuntungan dalam jangka waktu yang lama. Maka dari itu, instrumen wakaf uang dapat melengkapi zakat, infak, dan sedekah sebagai instrumen penggalangan dana sosial.

Dengan mayoritas penduduk Muslim terbesar mencapai 87\%, potensi wakaf di Indonesia sangat besar jika bisa dioptimalkan dan mampu memberikan kontribusi positif terhadap perekonomian nasional. Dengan diterbitkannya UU No. 41 Tahun 2004 tentang Wakaf, regulasi ini semakin mendorong untuk memberdayakan wakaf uang sebagai instrumen membangun kehidupan sosial ekonomi umat Islam. Melihat peluang besar dalam pemanfaatan aset wakaf di Indonesia yang mencapai 414 juta hektar dan apabila dinominalkan yaitu sebesar $\mathrm{Rp} 2.050$ triliun, mendorong untuk memberdayakan idle asset atau wakaf yang belum produktif tersebut. Lebih lanjut kepada instrumeninstrumen yang mendorong masyarakat dalam berwakaf, seperti wakaf uang yang dikolaborasikan dengan sukuk yang disebut Cash Waqf Linked Sukuk (CWLS). Instrumen dari lahirnya sukuk berbasis wakaf ini diinisiasi oleh Bank Indonesia, Badan Wakaf Indonesia, dan Kementerian Keuangan. 
Cash Waqf Linked Sukuk (CWLS) termasuk produk creative financing baru dari Indonesia dan pertama di dunia, yang menghasilkan dampak keberkahan sepanjang masa. Di Indonesia pemanfaatan wakaf produktif menjadi indikator peningkatan perwakafan yang progresif, karena apabila asetnya dikelola dapat menghasilkan keuntungan secara ekonomis. Pada tahun 2018 tercatat bahwa Indonesia telah memiliki 192 Nadzir wakaf uang, namun nyatanya pergerakan wakaf di Indonesia belum mencapai potensi yang ada. Menurut Badan Wakaf Indonesia potensi wakaf tunai di tanah air mencapai Rp. 180 triliun.

Namun dari jumlah yang ada hanya Rp. 400 miliar yang sudah terealisasi, BWI menargetkan tahun 2019 realisasi potensi wakaf uang mencapai Rp. 800 miliar. Dengan melihat potensi wakaf, Forum Wakaf Produktif Indonesia yang di dukung Bank Indonesia, menginisiasi mengenai skema wakaf uang yang diinvestasikan dalam bentuk pembelian Surat Berharga Syariah Negara (SBSN), M. Anwar Bashori (selaku Kepala Departemen Ekonomi dan Keuangan Syariah) menurutnya bahwa skema ini akan mendorong praktik berwakaf menjadi lebih luas.

Dengan adanya instrumen Cash Waqf Linked Sukuk (CWLS) berpotensi untuk meningkatkan aset wakaf, di mana sukuk yang di integrasikan dengan wakaf ini berguna untuk memberdayakan banyaknya tanah wakaf yang tidak produktif. Sukuk berperan sebagai instrumen untuk memobilisasi sedangkan wakaf mempunyai kapasitas dalam memperoleh income dana aktifitas keuangan yang produktif. Oleh karena itu kolaborasi antara sukuk dan wakaf ini dapat menjadi inovasi dalam menyediakan pembiayaan dalam rangka pembangunan ekonomi yang berkelanjutan.

Disisi lain, melihat begitu signifikan dan kontribusi Cash Waqf Linked Sukuk (CWLS) ini dalam mengembangkan ekonomi umat, serta ditopang oleh sifat inovasi sebagai karakter utama, maka perlu di analisis kesesuaian akad yang digunakan dan mekanismenya dengan berpijak pada prinsip Maqâshid asy-Syarî'ah, karena bagaimanapun, segala bentuk ekonomi yang terkait dengan ke syarî́ah-an diperlukan kajian tertentu untuk melahirkan pemahaman apakah Cash Waqf Linked Sukuk (CWLS) ini sesuai dengan prinsip Maqâshid asy-Syarî'ah atau tidak.

Penelitian ini bertujuan untuk menganalisis transaksi Cash Waqf Linked Sukuk (CWLS) dalam Perspektif Maqâshid Asy-Syarî'ah. 


\section{B. TEORI TENTANG CASH WAQF LINKED SUKUK (CWLS) DAN MAQÂSHID ASY-SYARÎ'AH}

\section{Teori Tentang Cash Waqf Linked Sukuk (CWLS)}

Secara bahasa sukuk dapat di artikan sebagai dokumen atau sertifikat. Istilah sukuk berasal dari bahasa Arab yaitu dari kata صكوف (șakk) dengan bentuk jamak صكوك (sukuk). Sedangkan ditinjau dari segi istilah, pengertian sukuk dapat mengacu pada beberapa definisi sebagai berikut:

Berdasarkan Accounting and Auditing Organization for Islamic Financial Institution (AAOIFI) Sharia Standard, sukuk didefinisikan sebagai sertifikat yang bernilai sama yang merepresentasikan bagian kepemilikan yang tak terbagi atas suatu aset berwujud, nilai manfaat aset (usufruct), dan jasa (services), atau atas kepemilikan aset dari suatu proyek atau kegiatan investasi tertentu.

Dalam ekonomi Islam, sukuk sebenarnya bukan instrumen keuangan yang baru. Sukuk telah lama dipergunakan sebagai instrumen keuangan dalam perdagangan domestik maupun internasional oleh para pedagang Muslim sejak awal perkembangan Islam (abad 6 masehi).

Sukuk merupakan salah satu instrumen pasar modal syariah yang semakin populer seiring pesatnya perkembangan industri keuangan syariah. Pada fase awal, sukuk dikenal dengan istilah obligasi syariah. Namun dari perspektif syariah, istilah obligasi syariah sebenarnya kurang begitu tepat karena sukuk bukanlah surat utang melainkan sertifikat yang mencerminkan bukti kepemilikan atas aset riil. Untuk itu kemudian diperkenalkan istilah sukuk investasi (investment sukuk), atau yang dapat disebut dengan istilah sukuk.

Sedangkan dalam Peraturan Badan Pengawas Pasar ModalLembaga Keuangan (sekarang telah menjadi Otoritas Jasa Keuangan) Nomor IX.A.13 tentang Penerbitan Efek Syariah, sukuk didefinisikan sebagai efek syariah berupa sertifikat atau bukti kepemilikan yang bernilai sama dan mewakili bagian yang tidak tertentu (syuyu'/undivided share) atas:

a. Aset berwujud tertentu (a'yan maujudat);

b. Nilai manfaat atas aset berwujud (manafi'ul a'yan); tertentu baik yang sudah ada maupun yang akan ada; 
c. Jasa (al khadamat) yang sudah ada maupun yang akan ada;

d. Aset proyek tertentu (maujudat masyru' mu'ayyan); dan

e. Kegiatan investasi yang telah ditentukan (nasyath istitsmarin khashah).

Sukuk negara didefinisikan sebagai Surat Berharga Negara yang diterbitkan berdasarkan prinsip syariah, sebagai bukti atas bagian penyertaan terhadap aset SBSN, baik dalam mata uang rupiah maupun valuta asing. Pengertian tersebut mengacu pada UU No. 19 tahun 2008 tentang Surat Berharga Syariah Negara.

Sebagai instrumen berbasis syariah, penerbitan sukuk negara memerlukan underlying asset baik berupa barang milik negara atau proyek APBN. Selain itu diperlukan juga Fatwa dan Opini syariah dalam setiap penerbitannya.

\section{a. Pengertian Cash Waqf Linked Sukuk (CWLS)}

Cash Waqf Linked Sukuk (CWLS) adalah produk investasi sukuk negara yang disediakan sebagai alternatif investasi bagi nadzir dalam mengelola wakaf uang dan dana sosial lainnya dalam mendukung program pemberdayaan ekonomi umat dan kegiatan sosial kemasyarakatan.

Dari sudut pandang pemerintah terkait Cash Waqf Linked Sukuk (CWLS) adalah sumber pendanaan alternatif dan penerbitannya tidak membebani Anggaran Pendapatan dan Belanja Negara atau Daerah (APBN/APBD). Dan juga dapat mengurangi ketergantungan hutang luar negeri serta menstabilkan ekonomi makro. Pada saat yang sama, menurut pandangan masyarakat instrumen ini menarik karena merupakan instrumen investasi sekaligus beramal yang aman dan terjamin pemerintah. Selain itu, masyarakat dapat menentukan target pembangunan dari dana ini sesuai dengan kebutuhan masyarakat. Adapun tujuan pengembangan sukuk wakaf atau Cash Waqf Linked Sukuk (CWLS) adalah sebagai berikut:

1) Memfasilitasi wakif agar dapat berwakaf uang secara lebih mudah dan aman.

2) Mendukung pengembangan pasar keuangan syariah, khususnya industri wakaf uang (cash waqf).

3) Mendorong diversifikasi bisnis perbankan syariah, melalui optimalisasi peran LKS PWU. 
4) Mendorong pengembangan ekosistem wakaf nasional, khususnya penguatan tata kelola dan kelembagaan wakaf nasional.

5) Bagian dari upaya pengembangan dan inovasi dibidang keuangan dan investasi sosial Islam di Indonesia.

6) Bagian dari upaya diversifikasi investor dan instrumen Surat Berharga Syariah Negara (SBSN).

Perkembangan instrumen Cash Waqf Linked Sukuk (CWLS) tidak dapat dipisahkan dari dukungan dan komitmen pemerintah bersama otoritas terkait untuk pengembangan sektor keuangan sosial syariah di Indonesia. Komitmen bersama ini di dokumentasikan dalam nota kesepahaman antara Kementrian Keuangan, Kementrian Agama, Bank Indonesia dan Badan Wakaf Indonesia tentang pengelolaan harta wakaf berupa uang melalui pengembangan Waqf Link Sukuk pada 1 November 2018 dalam rangka melakukan kerja sama pengelolaan dan pengembangan harta wakaf berupa uang melalui Surat Berharga Syariah Negara (SBSN).

Ruang lingkup nota kesepahaman ini meliputi:

1) Koordinasi pengembangan harta wakaf berupa uang melalui sukuk termasuk sukuk negara;

2) Koordinasi dalam rangka program sosialisasi dan edukasi kepada public terkait Cash Waqf Linked Sukuk (CWLS);

3) Tukar menukar data atau informasi terkait pengembangan Cash Waqf Linked Sukuk (CWLS), termasuk sarana pendukung yang dibutuhkan dalam kegiatan operasionalisasinya oleh masingmasing lembaga terkait;

4) Peningkatan kapasitas sumber daya manusia dalam rangka pengembangan Cash Waqf Linked Sukuk (CWLS);

5) Evaluasi perkembangan Cash Waqf Linked Sukuk (CWLS).

\section{b. Karakteristik Cash Waqf Linked Sukuk (CWLS)}

Sesuai kewenangan yang diberikan peraturan PerundangUndangan di bidang wakaf, Badan Wakaf Indonesia (BWI) dalam kedudukannya sebagai nadzir atau pengelola wakaf, melakukan penempatan dana atau wakaf uang dalam SBSN melalui mekanisme private placemant. CWLS yang diterbitkan adalah SBSN yang tidak 
dapat diperdagangkan (non-tradable), dan dengan imbal hasil investasi berupa diskonto dan kupon.

Adapun karakteristik Cash Waqf Linked Sukuk (CWLS) meliputi:

a. Untuk Individu dan Institusi.

b. Imbalan tetap, disalurkan ke program/kegiatan sosial.

c. Memiliki jangka waktu (tenor)

d. Pemesanan mulai dari 1 juta dan tidak ada maksimal pemesanan.

e. Setelah jatuh tempo $100 \%$ uang wakaf dikembalikan kepada wakif.

f. Tidak dapat diperjual-belikan (non-tradable).

\section{c. Upaya Pengumpulan Dana Cash Waqf Linked Sukuk (CWLS)}

Proses pengumpulan dana CWLS SW001 melewati berbagai dinamika di tengah rendahnya literasi masyarakat umum selaku investor tentang wakaf uang secara umum dan instrumen CWLS secara khusus. Rendahnya literasi tersebut, sempat menimbulkan keraguan dari para stakeholders, seperti BUMN, perusahaan swasta, pemerintah provinsi/daerah, dan perbankan untuk berpartisipasi pada instrumen baru ini. Selain itu terdapat kendala yang diakibatkan oleh regulasi, khususnya bagi perusahaan/BUMN untuk berinvestasi dalam instrumen ini. Terdapat keterbatasan pengaturan dalam UU Perseroan Terbatas mengenai treatment dana CSR (Corporate Social Responsibility) yang belum mengatur penempatan dana CSR pada instrumen sosial seperti CWLS yang berbasiskan wakaf.

Sebagai bentuk komitmen bersama untuk mewujudkan penerbitan CWLS SW001, pimpinan BWI, Kementrian Keuangan, Kementrian Agama, dan Bank Indonesia melakukan high level meeting guna mengatasi kendala yang dihadapi dalam proses awal pengumpulan dana CWLS SW001. Pertemuan ini memutuskan program utama untuk pemanfaatan imbal hasil CWLS seri SW001, yaitu Pembangunan Retina Center di Rumah Sakit Mata Achmad Wardi Serang. Ini adalah proyek unggulan pemanfaatan dana wakaf yang dikelola oleh BWI.

Dengan adanya satu program unggulan yang telah disepakati bersama, proses penyusunan konten marketing dapat dilakukan secara lebih baik, komprehensif, dan terarah. Dilakukan pula uji coba sistem 
operasional untuk memastikan seluruh proses penerbitan perdana CWLS dapat terlaksana dengan baik. Melihat semakin siap nya seluruh infrastruktur pendukung penerbitan perdana CWLS secara end to end, secara paralel dilakukan juga pendekatan kepada stakeholders potensial untuk semakin meyakinkan dan meningkatkan confident mereka untuk berpartisipasi dalam menyukseskan penerbitan perdana CWLS seri SW001. Proses ini dilakukan dengan menggunakan lingkaran pengaruh stakeholders utama yang pada akhirnya dapat mengakselerasi proses penghimpunan dana.

Untuk penerbitan-penerbitan CWLS seri berikutnya, perlu dirumuskan solusi yang tepat agar stakeholders yang belum berpartisipasi, seperti perusahaan/BUMN, dapat turut berinvestasi dalam instrumen ini. Opsi penerbitan instrumen CWLS daerah juga dapat di elaborasi untuk menarik minat pemerintah daerah dalam berinvestasi pada instrumen ini.

\section{d. Optimalisasi Cash Waqf Linked Sukuk (CWLS) untuk Pembiayaan Proyek Sosial}

Adapun optimalisasi Cash Waqf Linked Sukuk (CWLS) untuk pembiayaan proyek sosial adalah sebagai berikut:

a. Kesehatan: Penyediaan sarana pra sarana kesehatan gratis bagi dhuafa di RS Mata Achmad Wardi Serang, layanan kesehatan gratis untuk dhuafa yaitu operasi katarak gratis.

b. Infrastruktur: Pembiayaan infrastruktur sosial dan program sosial daerah seperti penjajakan wakaf produktif Provinsi Riau.

c. Kegiatan Sosial: Pengembangan Endowment Fund untuk lembaga sosial seperti Dana Kemaslahatan BPKH, pengembangan Dana CSR untuk kegiatan sosial seperti Dana CSR korporasi dan BUMN.

d. Perkebunan/Peternakan: Pemanfaatan lahan non produktif untuk peternakan/perkebunan potensi 420 ribu hektar seperti Wakaf Kebun Dompet Dhuafa.

e. Pemberdayaan UMKM: Pemberdayaan UMKM seperti Wakaf Produktif UMKM oleh Rumah Wakaf.

f. Umrah Gratis: Program Umrah gratis untuk guru-guru ngaji di daerah. 


\section{Teori tentang Maqâshid asy-Syarî'ah}

Jika melihat sejarah perkembangan ushul fiqih sebelum alSyatibi, tidaklah berlebihan kiranya jika dikatakan bahwa istilah maqasid al-syari'ah atau objektif syari'ah belumlah ditemukan secara eksplisit. Lebih-lebih mengenai pengertiannya sebagaimana yang telah dijelaskan sebelumnya. Konsep tersebut hanya dapat ditemukan dalam karya-karya ulama moderen yang diilhami oleh pemikiran beliau tentang maqasid al-syari'ah.

Pembicaraan mengenai maqasid al-syari'ah di era sebelum alSyatibi hanya dapat diidentifikasi secara implisit dalam tema-tema kajian 'illah hukum dan maslahat. 'Illah yang diartikan dengan suatu perkara yang jelas dan tegas yang menjadi alasan ditetapkannya hukum menjadi tema kajian yang menarik ketika dihubungkan dengan kajian maslahat. Sementara kajian 'illah ini juga memasuki wilayah kajian teologi ketika dihubungkan dengan pertanyaan apakah hukum yang ditetapkan Tuhan itu berdasarkan 'illahi (kausa) tertentu atau tidak. Untuk menjawab pertanyaan tersebut maka tidak bisa tidak, pasti melibatkan alasan-alasan teologis dan hukum. Ringkasnya dapat dikatakan bahwa semua ahli ushul sepakat tentang tujuan akhir dari hukum adalah satu yakni maslahah atau kebaikan dan kesejahteraan umat manusia.

Konkritnya, pengenalan dan pembahasan tentang konsep maqasid al-Syari'ah telah dimulai dari Imam al-Haramain al-Juwaini. Beliau dapat dikatakan sebagai ahli ushul pertama yang menekankan pentingnya memahami maqasid al-syari'ah dalam menetapkan hukum Islam. Ia secara tegas menyatakan bahwa seseorang tidak mampu menetapkan hukum sebelum benar-benar memahami tujuan Allah mengeluarkan perintah dan larangan. Lebih jauh ia mengelaborasi maqasid al-syari'ah tersebut dalam hubungannya dengan 'illat dan asl yang dapat dikategorikan ke dalam lima bagian, yaitu asl yang masuk dalam kategori dharuriyyat (primer), al-hajah al-'ammah (sekunder), makramat (tersier), sesuatu yang tidak termasuk kelompok dharuriyyat dan hajiyyat, dan sesuatu yang tidak termasuk ke dalam ketiga kelompok sebelumya. Singkatnya, al-Juwaini membagi asl atau tujuan tasyri' itu menjadi tiga macam yaitu dharuriyyat, hajiyyat, makramat (tahsiniyyat).

Selanjutnya, pemikiran al-Juwaini tersebut dikembangkan oleh muridnya yakni al-Ghazali. Beliau menjelaskan maksud syari'at dalam 
kaitannya dengan pembahasan al-munasabat al-maslahiyyat dalam qiyas dan dalam kesempatan yang lain ia menjelaskannya dalam tema istislah. Maslahat menurut al-Ghazali adalah memelihara agama, jiwa, akal, keturunan dan harta. Kelima macam maslahat di atas berada pada skala prioritas dan urutan yang berbeda jika dilihat dari sisi tujuannya yaitu peringkat primer, sekunder dan tersier. Dari keterangan tersebut terlihat bahwa maqasid al-Syari'ah sudah mulai menampakan bentuknya.

Pemikir dan ahli hukum Islam selanjutnya yang membahas secara khusus maqasid al-Syari'ah adalah Izzuddin ibn Abd al-Salam dari kalangan Syafi'iyyah. Ia lebih banyak menekankan dan mengelaborasi konsep maslahat secara hakiki dalam bentuk menarik maslahat dan menolak mafsadat. Menurutnya, maslahat keduniaan tidak dapat dilepaskan dari tiga tingkatan urutan skala prioritas, yaitu dharuriyyat hajiyyat dan takmilat atau tatimmat. Lebih jauh lagi ia menyebutkan bahwa taklif harus bermuara pada terwujudnya kemaslahatan manusia baik di dunia maupun di akhirat. Berdasarkan penjelasan ini dapat dikatakan bahwa Izzuddin telah berusaha mengembangkan maslahat yang merupakan inti pembahasan dari maqasid al-Syari'ah.

Penjelasan yang sistematis dan secara khusus serta jelas dilakukan oleh al-Syatibi dari kalangan Malikiyyah dalam kitabnya alMuwafaqat fi Usul al-Syari'ah. Dalam kitabnya yang terkenal tersebut, ia menghabiskan sepertiga dari bukunya untuk membahas maqasid alsyari'ah. Tentunya pembahasan tentang maslahat pun menjadi bagian yang sangat penting dalam pembahasannya. Ia dengan secara tegas menyatakan bahwa tujuan utama Allah menetapkan hukum-hukumNya adalah untuk terwujudnya kemaslahatan hidup di dunia dan akhirat. Karenanya, taklif harus mengarah pada terealisirnya tujuan hukum tersebut.Setiap suruhan dan larangan yang ada dalam ayat dan hadis tidak terlepas dari upaya memelihara kemaslahatan.

Fatkhi ad-Daraini mengomentari bahwa hukum-hukum tidaklah dibuat untuk hukum sendiri melainkan dibuat untuk tujuan kemaslahatan. Dengan bahasa yang tidak jauh berbeda Abu Zahrah menyatakan bahwa tujuan hakiki hukum Islam adalah kemaslahatan. Tidak satu pun hukum yang disyari'atkan baik dalam al-Qur'an maupun hadis melainkan di dalamnya terdapat kemaslahatan. 
Pernyataan di atas semakin mempertegas pernyataan al-Syatibi bahwa sesungguhnya syari' at itu bertujuan untuk mewujudkan kemaslahatan manusia di dunia dan akhirat.[9] Semua kewajiban diciptakan dalam rangka merealisasikan kemaslahatan hamba. Tak satupun hukum Allah yang tidak mempunyai tujuan hukum. Dapat dikatakan bahwa kandungan maqasid al-Syari'ah adalah kemaslahatan. Melalui analisis maqasid al-Syari'ah, kemaslahatan tidak hanya dilihat dalam arti teknis belaka akan tetapi dalam upaya dinamika dan pengembangan hukum, maqasid al-Syari'ah dilihat sebagai sesuatu yang mengandung nilai filosofis dari hukum-hukum yang disyari'atkan Tuhan kepada manusia.

Kemaslahatan yang menjadi tujuan syari'at ini dibatasi dalam lima hal, yaitu agama, jiwa, akal, keturunan dan harta. Setiap hal yang mengandung penjagaan atas lima hal tersebut disebut maslahah dan setiap hal yang membuat hilangnya lima hal disebut mafsadah. Dalam usaha untuk mewujudkan dan mempertahankan lima hal pokok tersebut, maka al-Syatibi membagi kemaslahatan tersebut pada tiga tingkatan, yaitu:

a. Kemaslahatan dharuri. Kemaslahatan ini adalah kepentingan yang harus ada untuk terwujudnya kemaslahatan dunia dan akhirat. Apabila kepentingan tersebut tidak ada maka kelangsungan hidup di dunia tidak dapat dipertahankan dan akhirat akan mengalami kerugian eskatologis. Kepentingan ini disebut juga dengan kepentingan primer. Menurut al-Syatibi, perlindungan terhadap lima kemaslahatan yang telah disebutkan di atas digolongkan ke dalam kategori kemaslahatan ini. Untuk mewujudkan tujuan ini disyari'atkan hukuman terhadap orang yang membawa dan menyebarkan ajaran sesat, disyari'atkannya qiyas yang bertujuan untuk melindungi jiwa, pidana dera untuk minum khamar yang bertujuan melindungi akal, pidana zina yang bertujuan melindungi keturunan, pidana pencurian untuk melindungi kekayaan orang yang merupakan sendi kehidupan manusia.

b. Kemaslahatan hajji, yakni kepentingan yang harus ada demi terwujudnya kemaslahatan yang tanpanya kemaslahatan hidup masih dipertahankan, akan tetapi dalam kesulitan dan tidak normal. Contohnya adalah pemberian hak kepada wali mujbir untuk mengawinkan anak dibawah umur Ini memang bukan merupakan suatu yang bersifat dharuri, akan tetapi sangat 
dibutuhkan dengan alasan supaya tidak kehilangan jodoh yang sepadan. Ini berbeda halnya dengan hak wali untuk melakukan pengurusan kepentingan pendidikan anak dan pemenuhan kebutuhan lainnya yang berada pada tingkat dharuri karena kebutuhan kepada nafkah dan pemeliharaan yang menyangkut kelangsungan hidup anak.

c. Kemaslahatan tahsini, yakni perwujudan kepentingan yang tidak bersifat dharuri dan tidak bersifat haji. Dengan kata lain, jika kepentingan ini tidak terwujud, maka tidak menyebabkan kesulitan apalagi mengancam kelangsungan hidup. Sifatnya hanyalah komplementer yang bertujuan untuk mewujudkan praktek ibadah dan muamalat yang lebih baik serta mendorong akhlak dan kebiasaan terpuji. Contohnya adalah pendapat Syafi'i yang melarang jual beli kotoran dan anjing serta semua benda najis. Alasannya dianalogikan dengan jual beli khamar dan bangkai karena najisnya. Penetapan kenajisan kedua benda tersebut mengisyaratkan pandangan bahwa benda tersebut kurang berguna. Kalau dibolehkan jual beli benda tersebut, berarti memberikan penilaian yang menghargai barang itu dan ini bertentangan dengan isyarat-isyarat yang menganggapnya sebagai benda tidak berharga.

Konsep maqasid al-Syari'ah yang dikembangkan oleh alSyatibi ini sebenarnya telah melampaui pembasan ulama abad-abad sebelumnya.Konsep al-maslahat al-Syatibi tersebut melingkupi seluruh bagian syari'ah dan bukan hanya aspek yang tidak diatur oleh nas saja.Meskipun begitu, pemikiran maslahat al-Syatibi ini tidak seberani gagasan at-Tufi.

Pandangan at-Tufi mewakili pandangan yang radikal dan liberal tentang maslahat. At-Tufi berpendapat bahwa prinsip maslahat dapat membatasi (takhsis) Alquran, sunnah dan ijma' jika penerapan nas Alquran, sunnah dan ijma' itu akan menyusahkan manusia. Akan tetapi, ruang lingkup dan bidang berlakunya maslahat at-Tufi tersebut adalah mu'amalah.

Berdasarkan berbagai pandangan para ulama di atas dapat ditarik sebuah kesimpulan bahwa mereka sepakat tentang tujuan Allah mensyari'atkan sebuah hukum adalah untuk memelihara kemaslahatan seluruh manusia, di lain sisi untuk menghindari 
mafsadat, baik di dunia maupun di akhirat. Tujuan tersebut dicapai lewat taklif, yang pelaksanaannya sangat tergantung pada pemahaman sumber hukum utama, al-Qur'an dan hadits. Dalam mewujudkan kemaslahatan manusia di dunia dan akhirat, ada lima hal pokok yang harus dipelihara dan dijaga yaitu agama, jiwa, akal, keturunan dan harta.

Konsep ini telah diakui oleh para ulama dan oleh karena itu mereka memformulasikan suatu kaidah yang cukup populer, "Di mana ada maslahat, di sana terdapat hukum Allah." Teori maslahat di sini menurut Masdar F. Masudi sama dengan teori keadilan sosial dalam istilah filsafat hukum. /Adapun inti dari konsep maqasid al-syari'ah adalah untuk mewujudkan kebaikan sekaligus menghindarkan keburukan atau menarik manfaat dan menolak mudarat, istilah yang sepadan dengan inti dari maqasid al-syari'ah tersebut adalah maslahat, karena penetapan hukum dalam Islam harus bermuara kepada maslahat.

\section{ANALISIS CASH WAQF LINKED SUKUK (CWLS) DALAM PERSPEKTIF MAQÂSHID ASY-SYARI' 'AH}

Dalam pengelolaannya, Cash Waqf Linked Sukuk (CWLS) memberikan dampak yang menguntungkan. Dana wakaf tersebut digunakan untuk mendorong perekonomian nasional. Adapun penyaluran manfaat imbal hasil CWLS antara lain sebagai berikut:

1. Mendukung pelaksanaan program sosial, digunakan untuk menyelesaikan pembangunan Retina dan Glaukoma Center RS Mata Achmad Wardi, Serang, Provinsi Banten.

2. Penangkaran benih padi, bantuan indukan sapi potong, beasiswa pendidikan, dan bantuan alat dengar, dilaksanakan oleh Yayasan BSM Umat selaku Nadzir.

3. Kesehatan klinik pesantren, beasiswa santri dhuafa, dan bantuan modal UMKM, dilaksanakan oleh LAZISNU selaku Nadzir.

4. Indonesian Mobile Clinic (Ambulance), Beasiswa Mentari, Beasiswa Sang Surya dan Bakti Guru dan pemberdayaan UMKM, dilaksanakan oleh LAZISMU selaku Nadzir.

5. Sahabat UKM, Beasiswa Sarjana Muamalat dan Beasiswa CIKAL (SD-SMA) dilaksanakan oleh Baitul Maal Muamalat.

6. Pembangunan Masjid Salman Rasidi, dilaksanakan oleh Wakaf Salman ITB selaku Nadzir. 
7. Wakaf Hunian Hasanah, Wakaf Asupan Sehat dan Wakaf Kemandirian Ekonomi Pesantren, dilaksanakan oleh Yayasan Hasanah Titik selaku Nadzir.

8. Pembiayaan pengobatan pasien dhuafa, Program Pendidikan Khadijah Learning Center (KLC), dan Pemberdayaan Ekonomi Pertanian Teknik Hidroponik, dilaksanakan oleh Dompet Dhuafa selaku Nadzir.

Ditinjau dari kemaslahatannya, Cash Waqf Linked Sukuk (CWLS) dapat memajukan keberlanjutan ekonomi. Hal ini menunjukkan bahwa terdapat sektor sosial dalam keuangan syariah yang dapat mendorong sektor komersial dan memberikan hubungan timbal balik, sehingga memberikan manfaat yang besar bagi kesejahteraan sosial dan pembangunan ekonomi yang berkelanjutan. Dengan cara inilah, Cash Waqf Linked Sukuk (CWLS) dapat menjadi sektor bisnis dan sektor sosial. Pembiayaan mengalir ke sektor-sektor produktif, menggerakkan ekonomi riil, dan hasil dari kegiatannya mengalir ke sektor-sektor sosial yang membutuhkan antara lain seperti perguruan tinggi, pengelolaan pembiayaan daerah pasca bencana dan sektor sosial yang lainnya.

Berbicara tentang mashlahat, Hukum Islam telah mengajarkan Ilmu Maqâshid asy-Syarî'ah, kendati yang menjadi tolak ukur dalam menetapkan sebuah kemaslahatan untuk kehidupan manusia adalah dengan mengamati kebutuhan-kebutuhan dasar hidup manusia.

Menurut Imam asy-Syathibi ada lima hal yang menjadi kebutuhan dasar bagi kehidupan manusia yang disebut dengan adhdharuriyyâh al-khamsah, yakni memelihara agama (hifdz ad-dîn), jiwa (hifdz an-nafs), akal (hifdz al-'aql), keturunan (hifdz an-nasl) dan harta (hifdz al-mâl).

Kelima maqâshid tersebut bertingkat-tingkat sesuai kepentingannya, tingkatan kepentingan tersebut ada 3 yaitu: Dharuriyât, Ḥajiyyât dan Taḥsiniyyât.

Dari penjelasan di atas mengenai ketentuan akad yang digunakan dalam mekanisme pelaksanaan Cash Waqf Linked Sukuk (CWLS) sudah sesuai dengan prinsip-prinsip syariah dan memberikan dampak positif yang cukup besar untuk pengembangan keberlanjutan ekonomi. Menurut penulis, jika ditinjau dari perspektif maqâshid 
syarî'ah nya Cash Waqf Linked Sukuk (CWLS) ini telah membawa kemaslahatan atau hajat dalam kehidupan manusia dan menghindari kemudharatan. Bahwa setiap perilaku yang bertujuan untuk memenuhi kelima hajat itu adalah mashlaḥat, atau sebaliknya jika setiap perilaku yang menghilangkan kelima hajat itu adalah mafsadat. Kelima hajat tersebut adalah sarana untuk menunaikan tujuan manusia yaitu menjadi hamba Allah Swt. Imam Asy-Syatibi menyimpulkan:

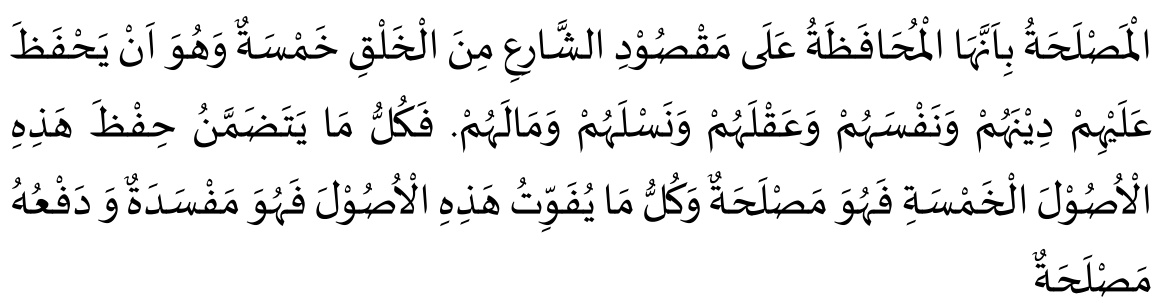

"Mashlahat adalah memenuhi tujuan Allah Swt. yang ingin dicapai pada setiap makhluknya. Tujuan tersebut ada lima, yaitu melindungi agamanya, jiwanya, akalnya, keturunannya dan hartanya. Standarnya, setiap usaha yang merealisasikan lima maqashid tersebut, maka itu termasuk mashlahat. Dan sebaliknya, setiap usaha yang menghilangkan lima maqashid tersebut, maka termasuk mafsadat".

Dari kelima hajat tersebut, Cash Waqf Linked Sukuk (CWLS) termasuk kedalam kategori hiffzz al-mâl tingkat ḥajiyyât karena pengembangan investasi wakaf uang ini termasuk dianjurkan untuk dilakukan mengingat potensi aset wakaf yang begitu besar untuk pengembangan ekonomi berkelanjutan. Termasuk juga kategori hifdz ad-dîn tingkat hajiyyât karena sebagai bekal di akhirat dan upaya memelihara nilai-nilai agama karena sesama Muslim itu dianjurkan untuk tolong-menolong serta untuk tetap melestarikan keutuhan wakaf.

Maka dari itu, karena potensi Cash Waqf Linked Sukuk (CWLS) sangat besar untuk dijadikan produktif dan juga sebagai sarana investasi dunia dan akhirat yang berlandaskan dengan prinsip-prinsip syariah, keberadaan CWLS ini cocok untuk diterapkan di Indonesia dalam rangka mencapai kemashlahatan dan kesejahteraan masyarakat. 


\section{KESIMPULAN}

Penelitian ini memberikan temuan bahwa transaksi Cash Waqf Linked Sukuk (CWLS) jika ditinjau dari perspektif Maqâshid Syarî'ah termasuk dalam kategori hifdz al-mâl tingkat hajiyyât karena pengembangan investasi wakaf uang ini termasuk dianjurkan untuk dilakukan mengingat potensi aset wakaf yang begitu besar untuk pengembangan ekonomi yang berkelanjutan. Termasuk juga kategori hifdz ad-dîn tingkat hajiyyât karena sebagai bekal di akhirat dan upaya memelihara nilai-nilai agama karena sesama muslim itu dianjurkan untuk tolong-menolong dan untuk tetap melestarikan keutuhan wakaf.

\section{DAFTAR PUSTAKA}

Muhammad Khalid. (1995). Filsafat Hukum Islam dan Perubahan Sosial, terj. Yudian Wahyudi Asmin. Sarabaya: al-Ikhlas.

Ar-Raisuni. (1992). Nazariyyah al-Maqosid 'inda al-Imam al-Syatibi. Riyadh: Dar al-Ilmiyyah al-Kitab al-Islami.

Fatkhi al-Daraini. (1975). al-Manahij al-Usuliyyah fi Ijtihad bi al-Ra'yi fi Tasyri'. Damaskus: Dar al-Kitab al-Hadis.

Muhammad Abu Zahrah. (1958). Ushul al-Figh. Kairo: Dar al-Fikr al'Arabi.

Al- Syatibi. (tt.). Al-Muwafaqat fi Usul al-Syari'ah. Kairo: Mustafa Ahmad.

Muhammad Said Romadhon al-Buti. (1992). Dawabit al-Maslahah fi alSyari'ah al-Islamiyyah. Beirut: Dar al-Muttahidah.

Nur A. Fadhil Lubis. (1995). Hukum Islam dalam Kerangka Teori Fikih dan Tata Hukum Indonesia. Medan: Pustaka Widyasarana.

Najmuddin at-Tufi. (1954). Syarah al-Hadis Arba'in an-Nawaiyah dalam Mustafa Zaid, 1954. al- Maslahat fi at- Tasyri'i al- Islami wa Najmuddin at- Tufi. Kairo: Dar al-Fikr al-Arabi.

Muhammad Sa'id Ramdan al-Buti. (1977). Dawabit al-Maslahah fi asSyari'ah al-Islamiyah. Beirut: Mu'assasah ar-Risalah.

Barkah, Qadariah et.al (2020). Fikih Zakat, Sedekah dan Wakaf. Jakarta: Kencana. 
Direktorat Pembiayaan Syariah dan Direktorat Jenderal Pengelolaan Pembiayaan dan Risiko. (2021). Cash Waqf Linked Sukuk Seri SWR002 (Materi Marketing). Jakarta: t.tp.

Hariyanto, Eri. (2017). Mengenal Sukuk Negara. Yogyakarta: Gava Media.

Ibn Musa al-Lakhmi al-Gharnathi al-Maliki, Abu Ishaq Al-Syatibi Ibrahim. (2011). Al-Muwafaqat fi Ushul asy-Syari'ah, Juz II, Jilid I. Beirut: Dar al-Kutub.

Kemenkeu Republik Indonesia, et. al. (2021). Annual Report: Cash Waqf Linked Sukuk. Jakarta: Kemenkeu RI.

Mubarak, Jaih dan Hasanuddin. (2017). Fikih Mu'amalah Maliyyah Akad Tabarru. Bandung: Simbiosa Rekatama Media. 